\title{
Modified phacoemulsification in oculocutaneous albinism to reduce photophobia
}

\author{
Zoltán Sohajda · Noémi Széll · Judit Hayfron · Andrea Facskó
}

Received: 12 February 2020 / Accepted: 31 March 2020 / Published online: 24 April 2020

(C) The Author(s) 2020

\begin{abstract}
Summary
Background The main ophthalmological signs of oculocutaneous albinism (OCA) are the translucency of the iris and photophobia. We describe an alternative method to reduce photophobia after cataract removal in OCA patients.

Material and methods A 53-year-old woman suffered from OCA and bilateral cataract. Phacoemulsification was performed via posterior capsulorhexis with implantation of a three-piece intraocular lens into the sulcus ciliaris of the left eye and secondly of the right eye.

Results We expected a fibrosis to be formed between the two capsular surfaces, which consequently would improve the diaphragm function of the iris and thus reduce photophobia. In the postoperative period, visual acuity and contrast sensitivity improved continuously, whereas photophobia decreased.

Conclusion This modified surgical method is easy to perform. It is very cost-effective and can reduce photophobia and improve contrast sensitivity in albino patients in the long term.
\end{abstract}

Keywords Oculocutaneous albinism - Cataract . Photophobia · Posterior capsulorhexis · Three-piece IOL

\section{Z. Sohajda $(\bowtie) \cdot N$. Széll}

Department of Ophthalmology Kenézy

Gyula Hospital, University of Debrecen,

Bartók Béla str. 2-26, 4031 Debrecen, Hungary

zoltansohajda@hotmail.com

\section{J. Hayfron}

AugenCentrum Südwest Stuttgart, Stuttgart, Germany

\section{A. Facskó}

Department of Ophthalmology, Szent-Györgyi Medical

Center University of Szeged, Szeged, Hungary

\section{Modifizierte Phakoemulsifikationstechnik zur Minderung der Photophobie bei okulokutanem Albinismus}

\section{Zusammenfassung}

Hintergrund Beim okulokutanen Albinismus (OCA) bestehen die ophthalmologischen Hauptsymptome aus Transluzenz der Iris und Photophobie. Die Autoren beschreiben eine Alternativmethode zur Verminderung der Photophobie nach Kataraktentfernung bei OCA-Patienten.

Material und Methoden Eine 53-jährige Frau litt unter OCA und bilateraler Katarakt. Es wurde eine Phakoemulsifikation via posteriore Kapsulorhexis durchgeführt mit Implantation einer dreiteiligen Intraokularlinse in den Sulcus ciliaris erst des linken Auges und dann auch des rechten Auges.

Ergebnisse Die Autoren erwarteten, dass sich eine Fibrose zwischen den beiden kapsulären Oberflächen ausbildete, die somit die Blendenfunktion der Iris verbessern und folglich die Photophobie vermindern würde. In der postoperativen Phase verbesserten sich Sehschärfe und Kontrastempfindlichkeit kontinuierlich, während die Photophobie abnahm.

Schlussfolgerung Das beschriebene modifizierte chirurgische Vorgehen ist einfach in der Durchführung. Es ist sehr kostengünstig und kann bei Albinopatienten langfristig eine Photophobie vermindern sowie die Kontrastempfindlichkeit steigern.

Schlüsselwörter Okulokutaner Albinismus .

Katarakt · Photophobie · Posteriore Kapsulorhexis .

Dreiteilige Intraokularlinse

\section{Introduction}

Oculocutaneous albinism (OCA) is an autosomal recessive disorder featuring hypopigmentation of the 
hair, skin, and eyes. The prevalence of the disease is: $1 / 17,000$. Four genetic variations of OCA are known. Ocular signs associated with the disease are nystagmus, decreased visual acuity, hypopigmentation of the retina, foveal hypoplasia, translucency of the iris, impaired function of the iris diaphragm, macular transparency, abnormal decussation of nerve fibers at the chiasm, and photophobia [1]. Photophobia can disturb OCA patients very intensely especially after cataract surgery [2, 3]. We describe an alternative method to avoid the considerable photophobia encountered in OCA patients following cataract removal.

\section{Case report}

All procedures adhered to the Declaration of Helsinki. Written consent was obtained from the patient for the publication of her case and images. A 53-yearold woman suffered from hypopigmentation of the skin and hair from birth. She presented with horizontal nystagmus. On examination, visual acuity with best myopic correction was 0.04 (decimal) on both sides. Biomicroscopy of the anterior segment revealed a translucent iris with nuclear and cortical cataract in both lenses. At fundus examination, hypopigmented retina and partly missing pigment epithelium in the macular regions were detected. Intraocular pressure was normal.

The surgical procedure was as follows: phacoemulsification via phaco chop technique and posterior capsulorhexis, implantation of a three-piece intraocular lens (MA60AC, Alcon, Fort Worth, TX, USA) into
Table 1 Postoperative change in contrast sensitivity

\begin{tabular}{|l|l|l|l|l|}
\hline & $3 \mathrm{c} / \mathrm{d}$ & $6 \mathrm{c} / \mathrm{d}$ & $12 \mathrm{c} / \mathrm{d}$ & $18 \mathrm{c} / \mathrm{d}$ \\
\hline 1 Week & R: $5 / \mathrm{L}: 5$ & R: $8 / \mathrm{L}: 8$ & R: 4/L: 4 & R: $1.5 / \mathrm{L}: 1.5$ \\
\hline 4 Months & R: 43/L: 31 & R: 50/L: 36 & R: 18/L: 18 & R: 4.5/L: 4.5 \\
\hline 12 Months & R: 61/L: 43 & R: 70/L: 50 & R: 25/L: 25 & R: 7/L: 4.5 \\
\hline
\end{tabular}

Normative values of contrast sensitivity in the $50-75$-year age group under mesopic conditions on $3 \mathrm{c} / \mathrm{d}: 43,6 \mathrm{c} / \mathrm{d}: 70,12 \mathrm{c} / \mathrm{d}: 35,18 \mathrm{c} / \mathrm{d}: 9.5$ [5] $c / d$ Cycles per degree, $R$ right eye, $L$ left eye

the sulcus ciliaris on the right and, following this, on the left side. The size of the capsulorhexis was $4.5 \times 5.0 \mathrm{~mm}$ on the anterior and $3.0 \times 3.5 \mathrm{~mm}$ on the posterior capsule. Neither intraoperative nor postoperative complications were encountered. We expected a fibrosis to be formed between the two capsular surfaces, which would consequently improve the diaphragm function of the iris and reduce photophobia. The fibrosis between the two capsular surfaces became increasingly definitive (Figs. 1 and 2). In the postoperative period, visual acuity improved continuously up to 0.1 (decimal), whereas photophobia gradually decreased. The extent of nystagmus was similarly reduced at the end of the follow-up period, which was reported by the patient subjectively. We followed Chung's method to measure photophobia, using the CSV-1000 Contrast Sensitivity Chart under mesopic conditions with glare [4]. We encountered significant improvement in monocular contrast sensitivity from the 1st to the 52nd week, on lower spatial frequencies (three and six cycles per degree $[c / d]$ ). On
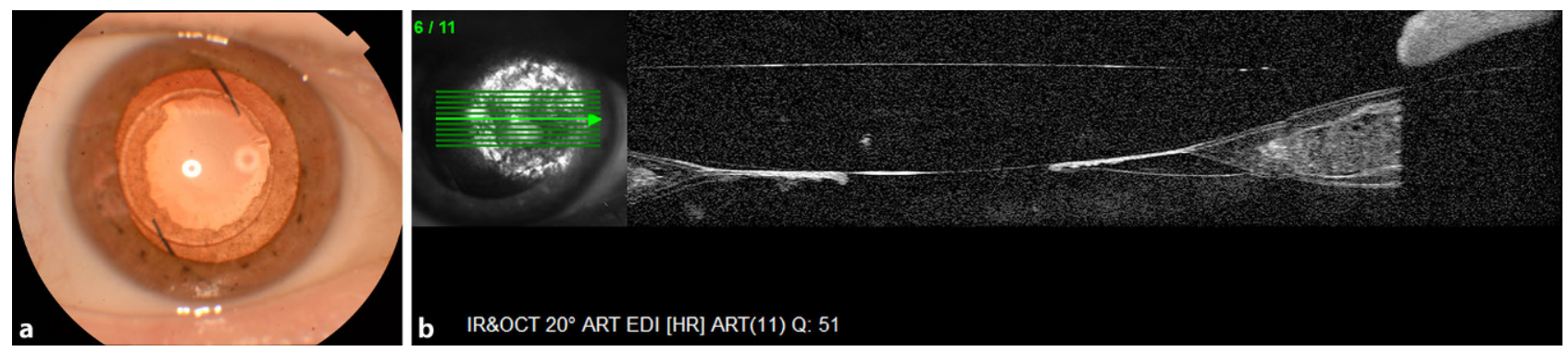

Fig. 1 a Right posterior capsule opacification can be clearly seen in anterior segment photograph 14 months after surgery. b Central capsulorhexis surrounded by thick posterior capsule
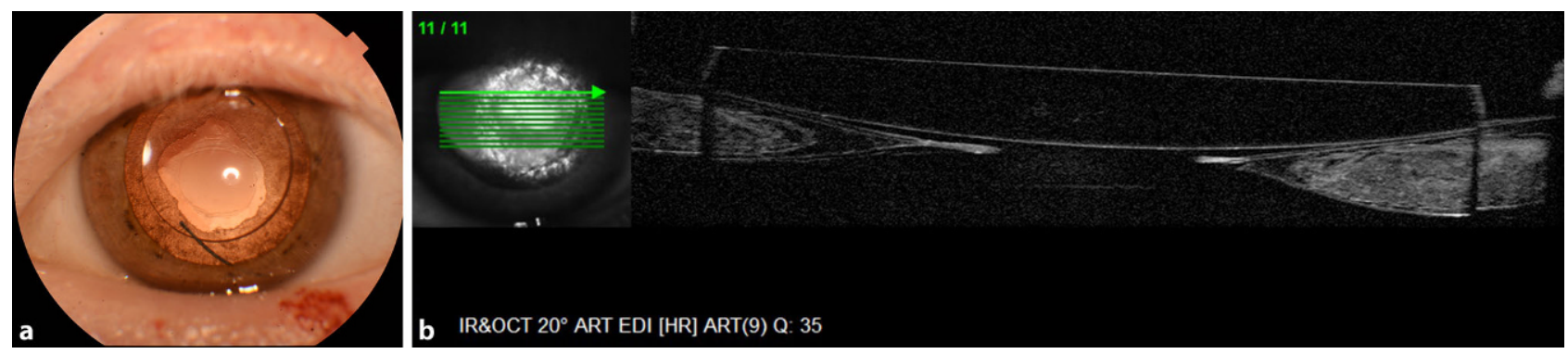

Fig. 2 a Left posterior capsule thickening in anterior segment photograph 12 months postoperatively. b Well-positioned intraocular lens with clear central area on the thick posterior cap- depicted in right anterior segment optical coherence tomography image 14 months after surgery

sule can be seen in left anterior segment optical coherence tomography image 12 months after surgery 
higher spatial frequencies (12 and $18 \mathrm{c} / \mathrm{d}$ ), we did not find such significant improvement (Table 1).

\section{Discussion}

After cataract surgery, photophobia can increase more intensely in patients with OCA than in those without OCA $[2,3]$. The diameter of the implanted intraocular lens is smaller than that of the crystalline lens, which may account for the increased photophobia. Translucency of the hypopigmented iris is increased, and accordingly light reflection at the edge of the intraocular lens will be similarly intensified. Therefore, it is important to combine cataract surgery on OCA patients with a technique suitable to reduce transillumination of the iris $[2,6]$. According to relevant international literature, the following possibilities exist to reduce photophobia after cataract surgery in OCA: fitting prosthetic contact lenses, implanting iriscolored intraocular lenses, aniridia rings with special lamellae, or prosthetic iris devices. However, these methods may have many advantageous but also disadvantages. The use of prosthetic contact lenses can reduce photophobia significantly without any surgical intervention, although the possibility of infectious keratitis with this procedure must be kept in mind [7]. Iris-colored intraocular lenses are very effective in reducing photophobia, but they are available only in non-foldable version, and therefore a larger corneal/ corneoscleral wound has to be made. Implantation of the intraocular lens into the capsular bag may cause problems, too. [3]. Special aniridia rings and prosthetic iris devices may be implanted through a clear corneal incision to reduce the photophobic phenomenon. These approaches require special surgical methods and instrumentation, on the one hand, and they increase the intraoperative complication rate, on the other hand. The fragility of iris ring lamellae may be another problem encountered intraoperatively. In addition, we must take into consideration that intraocular pressure elevation is more likely to occur in such cases, as rings located in the capsular bag beside the intraocular lens or the artificial iris located in the sulcus ciliaris may both narrow the angle. Another very significant point is that these special implants are rather expensive [2, 3, 6]. Assessment of photophobia is based on a subjective method. Several authors evaluated OCA patients' photophobia on a subjective scale or just after the patient's own report [2, 6]. Photophobia cannot be measured objectively in a direct way. In such cases, contrast sensitivity testing may be helpful. Measurement of contrast sensitivity in OCA patients after cataract surgery has not been discussed to date. This measurement method provides numerical data that are objectively comparable at different end points in the follow-up period. Contrast sensitivity increases rapidly postoperatively, and remains stable thereafter in patients without OCA. By contrast, in OCA patients, considerable photophobia may produce low contrast sensitivity levels after routine cataract surgery. In the case of our OCA patient, the change in lower spatial frequencies was significantly greater postoperatively, owing to the cataract removal. It changed slowly directly after the surgery and continued to grow thereafter. On higher spatial frequencies (12 and $18 \mathrm{c} / \mathrm{d}$ ) we did not find a similarly significant improvement due to the poor macular status of our patient. Accordingly, testing contrast sensitivity can help us to evaluate the efficacy of the surgery. An aperture larger than $4.0 \mathrm{~mm}$ in OCA patients enhances light reflection at the edges of the intraocular lens $[2,6]$. Therefore, we made an effort to create a capsulorhexis not larger than the diameter of the intraocular lens. As an additional result, the patient's nystagmus was reduced, which was assessed according to the patient's subjective judgment. Farahi objectively verified this finding measuring nystagmus by electronystagmography in OCA patients after cataract surgery and aniridia ring implantation. She found improvement of visual acuity and reduction of photophobia in the background [2].

Phacoemulsification with posterior capsulorhexis and implantation of a three-piece intraocular lens into the sulcus ciliaris effectively reduced the photophobia in our OCA patient. The method presented here is easy to perform and has only a minimal complication rate, as it applies the ordinary surgical method. Moreover, it is highly cost-effective and can reduce photophobia and improve contrast sensitivity in OCA patients in the long term.

Funding Open access funding provided by University of Debrecen (DE).

Conflict of interest Z. Sohajda, N. Széll, J. Hayfron, and A. Facskó declare that they have no competing interests.

Open Access This article is licensed under a Creative Commons Attribution 4.0 International License, which permits use, sharing, adaptation, distribution and reproduction in any medium or format, as long as you give appropriate credit to the original author(s) and the source, provide a link to the Creative Commons licence, and indicate if changes were made. The images or other third party material in this article are included in the article's Creative Commons licence, unless indicated otherwise in a credit line to the material. If material is not included in the article's Creative Commons licence and your intended use is not permitted by statutory regulation or exceeds the permitted use, you will need to obtain permission directly from the copyright holder. To view a copy of this licence, visit http://creativecommons.org/licenses/by/4.0/.

\section{References}

1. Grønskov K, Ek J, Brondum-Nielsen K. Oculocutaneous albinism. Orphanet J Rare Dis. 2007;2:43-51.

2. Farahi A, Hashemi H, Mehravaran S. Combined cataract surgery and aniridia ring implantation in oculocutaneous albinism. J Cataract Refract Surg. 2005;41(11): 2438-43. 
3. Wong VW, Lam PT, Lai TY, et al. Black diaphragm aniridia intraocular lens for aniridia and albinism. Graefes Arch Clin Exp Ophthalmol. 2005;243(5):501-4.

4. Chung SA, Rhiu S, Han SH, Lee JB. Photophobia measurement in intermittent exotropia using the contrast sensitivity test. Graefes Arch Clin Exp Ophthalmol. 2013;251(5):1405-11.

5. VectorVision CSV-1000 Product Manual 1991.
6. Karatza EK, Burk SE, Snyder ME, et al. Outcomes of prosthetic iris implantation in patients with albinism. J Cataract RefractSurg. 2007;33(10):1763-9.

7. Kruijt B, Franssen L, Prick LJ, et al. Ocular straylight in albinism. Optom Vis Sci. 2013;88(5):585-92.

Publisher's Note Springer Nature remains neutral with regard to jurisdictional claims in published maps and institutional affiliations. 